\title{
Phytochemistry, antioxidant potential and antifungal of Byrsonima crassifolia on soil phytopathogen control
}

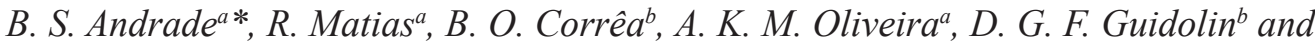 \\ A. R. Roelc
}

aPrograma de Pós-graduação em Meio Ambiente e Desenvolvimento Regional, Universidade Anhanguera - UNIDERP, Rua Alexandre Herculano, 1400, Jardim Veraneio, CEP 79037-280, Campo Grande, MS, Brazil

bPrograma de Pós-graduação em Produção e Gestão Agroindustrial, Universidade Anhanguera - UNIDERP, Rua Alexandre Herculano, 1400, Jardim Veraneio, CEP 79037-280, Campo Grande, MS, Brazil

'Programa de Pós-graduação em Ciências Ambientais e Sustentabilidade Agropecuária, Universidade Católica Dom Bosco - UCDB, Av. Tamandaré, 6000, Jardim Seminário, CEP 790117-900, Campo Grande, MS, Brazil

*e-mail: andradebrunad@gmail.com

Received: July 12, 2016 - Accepted: August 12, 2016 - Distributed: February 28, 2018

(With 5 figures)

\begin{abstract}
The use of chemical defensives to control fungal diseases has by consequence to impact negatively over the environment and human health, this way, the use of plant extracts with antifungal properties along with proper cultural management makes viable an alternative plant production control, specially for familiar and organic cultures. The objective of this study was to perform phytochemical and antioxidant analysis of Byrsonima crassifolia (canjiqueira) barks and evaluate its antifungal potential over Fusarium solani and Sclerotinia sclerotiorum mycelial growth. The ethanol extract from plants collected in Pantanal, Mato Grosso do Sul, Brazil was submitted to phytochemical prospection, total phenol and flavonoids quantification and antioxidant activiy determination (DPPH). To evaluate antifungal activity concentrations of 800, 1200, 1600, 2000 and $2400 \mu \mathrm{g} 100 \mathrm{~mL}^{-1}$ of ethanol extract were used. Which concentration was separately incorporated in agar (PDA) and shed in Petri dishes, followed by the fungi mycelial disc where the colonies diameter was measured daily. Negatives control with agar without extract and agar with an ethanol solution were used. The $B$. crassifolia ethanol extract presented inhibitory activity over the fungi studied where concentrations of 800 and $1600 \mu \mathrm{g} 100 \mathrm{~mL}^{-1}$, inhibited $38 \%$ of the mycelial growth of $F$. solani; to $S$. sclerotiorum the best concentration was $2400 \mu \mathrm{g} 100 \mathrm{~mL}^{1}$, reducing $37.5 \%$. The antifungal bark extract potential of this specie is attributed to phenolic compounds and to triterpenes derivatives.
\end{abstract}

Keywords: canjiqueira, plant fungicide, phenolic compounds, Fusarium solani, Sclerotinia sclerotiorum.

\section{Fitoquímica, potencial antioxidante e antifúngico de Byrsonima crassifolia no controle de fitopatógenos de solo}

\begin{abstract}
Resumo
A aplicação de defensivos químicos para o controle de doenças fúngicas tem por consequência impactos sobre o ambiente e a saúde humana, dessa forma, a utilização de extratos vegetais com propriedades antifúngicas associado ao manejo adequado de culturas, torna-se uma proposta viável de controle alternativo, principalmente na agricultura orgânica e familiar. Neste sentido, objetivou-se neste trabalho realizar a análise fitoquímica e antioxidante das cascas de Byrsonima crassifolia (canjiqueira) e avaliar seu potencial antifúngico sobre o crescimento micelial de Fusarium solani e Sclerotinia sclerotiorum. O extrato etanólico das cascas da planta, coletadas no Pantanal do Rio Negro, em Mato Grosso do Sul, foi submetido à prospecção fitoquímica, quantificação de fenóis totais e flavonoides e determinação da atividade antioxidante (DPPH). Para a avaliação da atividade antifúngica foram utilizadas as concentrações de 800 , 1200, 1600, 2000 e $2400 \mu \mathrm{g} 100 \mathrm{~mL}^{-1}$ do extrato etanólico. Cada concentração foi incorporada, separadamente, em ágar BDA, e vertida em placas de petri, seguido do disco de micélio do fungo, onde o diâmetro das colônias foi medido diariamente. Utilizou-se como controle negativo, ágar sem extrato e ágar com solução etanólica. O extrato etanólico de $B$. crassifolia apresentou atividade inibitória sobre os fungos estudados, onde as concentrações de 800 e $1600 \mu \mathrm{g}$ $100 \mathrm{~mL}^{-1}$, inibiram $38 \%$ do crescimento micelial de F. solani; para S. sclerotiorum, a melhor concentração foi de $2400 \mu \mathrm{g} 100 \mathrm{~mL}^{1}$, com 37,5\% de redução de crescimento. Atribui-se o potencial antifúngico do extrato da casca da espécie aos compostos fenólicos e derivados de triterpenos.
\end{abstract}

Palavras-chave: canjiqueira, fitofungicida, compostos fenólicos, Fusarium solani, Sclerotinia sclerotiorum. 


\section{Introduction}

Phytopathogenic fungi affect different crops, being responsible for economic losses in agricultural production. Among these disease-causing organisms highlights the ones that are found in soil, considered a difficult control problem, since they produce resistance structures and can survive for several years, such as Fusarium solani (Mart.) Sacc and Sclerotinia sclerotiorum (Lib.) from Bary (Bueno et al., 2007).

Different kinds of chemical products are used to control these fungi, however their incorrect application may lead to several impacts on natural resources and in human health, another potential effect is the selection of resistant pathogens to agrotoxics (Celoto et al., 2008).

Utilizing natural products to control plant diseases is becoming a promising alternative to reduce using agrotoxics (Zacaroni et al., 2009). Celoto et al. (2008) pointed that vegetal extracts have antifungal potential and may be used as a model to synthesise new fungicides or be directly applied by the producer.

This way, the use of vegetal extracts to control or inhibit phytopathogens represents a viable alternative for organic and family farmers, once the measures used by great farmers to control those agents, using massive quantities of chemicals, do not match small producers reality (Silva et al., 2009).

Family farmers in the State of Mato Grosso do Sul, Brazil, contributes to develop local agribusiness, mainly providing supply for families, reducing rural flight and generating work and income (Sangalli and Schlindwein, 2013). Beyond that, family farmers use more environmentally balanced practices, contributing to culture diversification and reducing the use of industrial inputs (Padua et al., 2013). This way, plants prospect ion becomes relevant to the growth of family farm in the State, according to the agricultural Census held in 2006, this activity answer for $65 \%$ of the properties, producing beans, corn, soy, wheat and other crops (IBGE, 2009). The great biodiversity found in the region is related to biome Cerrado and also the presence of Pantanal, a wetland. These formations represents a wealth biodiversity of vegetal species, lot of them are well known and used medicinally (Oliveira et al., 2011), with potential to be investigated as their insecticide, bactericide and fungicide activities, which can point their future use in sustainable farming practices.

Among these species of interest, there is Byrsonima crassifolia (L.) Kunth (Malpiguiaceae), a shrub found in Brazilian north and northeast coast (Pereira and Freitas, 2002). In Pantanal this specie is commonly called "canjiqueira" and occurs mainly on forest edges called "capões", besides it is also found in open fields (Pott and Pott, 1994; Pott et al., 2011). Their leaves and bark are used medicinally and one of its biological activities is an antimicrobial effect (Martínez-Vázquez et al., 1999) and bactericide and fungicide activities against several human pathogens (Guilhon-Simplicio and Pereira, 2011).
Considering its biological action variety, it becomes relevant to investigate its antifungal potential, controlling common agricultural phytopathogens which promote crops and financial loss specially for family farmers. This way, the aim of this study is to realize phytochemistry and antioxidant analysis of the Byrsonima crassifolia barks and evaluate its antifungal potential over the mycelial growth of Fusarium solani and Sclerotinia sclerotiorum.

\section{Material and Methods}

The barks of Byrsonima crassifolia were collected from 15 plants at the Rio Negro sub-region of Pantanal (19³0'18'S; 55³6'45'W), Mato Grosso do Sul, Brazil. The gathering occurred using a stainless chisel; after that a thick layer of petrolatum was applied on the affected area to avoid possible pathogens attack. The botanic material was conditioned in paper bags and transported to the laboratory. Specimens samples were deposited in the Herbarium of the Institution under the voucher number 07515.

\subsection{Phytochemical analysis}

The material was cleaned, dried in circulating air oven at $40^{\circ} \mathrm{C}\left(\mathrm{MARCONI}^{\circledR}, \mathrm{MA} 35\right)$, and finely ground in a Wiley mill (MARCONI ${ }^{\circledR}$, MA048). The powder $(500 \mathrm{~g})$ was extracted with ethanol $(99.5 \%)$ in ultrasound bath (ultrasonic Cleaner ${ }^{\circledR}$ ) for 60 minutes, followed by extraction by maceration during 7 days. The resultant solution was filtered and the solvent was evaporated, obtaining the ethanol extract, which was subjected to chemical analysis.

The phytochemical prospection occurred through characterization reactions, evaluating the presence of phenolic compounds, tannins, flavonoids, free coumarins, anthocyanins, anthraquinone, steroids, triterpenes, alkaloids, saponins, cardiotonic glycosides, cyanogenic heterosides and reducing sugar, all analyzes were performed in triplicate following methodology adapted by Matos (2009). For results of the assays were observed the alterations in the color and/or precipitation when compared with control, following the method of Fontoura et al. (2015), being strongly positive $(+++)$, moderadately positive $(++)$, weakly positive $(+)$ and parcialy positive $( \pm)$, but whether only haze and / or partially changed color also the absence of color and / or precipitation it was considerate as negative (-). The intensity of color and / or precipitation indicates the increased concentration of such class of secondary metabolite. Extracts were submitted to Bial, Seliwanoff, Barfoed and Iodine tests for sugars classification (Remião et al., 2003).

To confirm major components, $400 \mu \mathrm{m} \mathrm{mL}^{-1}$ of the extract was analysed through scanning spectrophotometer $\left(\right.$ FEMTO $^{\circledR}$, Modelo 432). Samples absorption aspects were measured from the $200 \mathrm{~nm}$ to $750 \mathrm{~nm}$ region using quartz cuvettes (Hellma, Müllheim, Germany), with three repetitions (Silverstein et al., 2014).

The extract was also submitted to $\mathrm{pH}$ analysis (DM-20, Digimed), concentration of soluble solids was determined by means of digital refractometer (45 RTD-refractómetro), being the results expressed in ${ }^{\circ} \mathrm{Brix}$, corrected for $20^{\circ} \mathrm{C}$. 


\subsection{Total phenol and flavonoids classification}

Ethanol extracts (100 mg each) were used to quantify total phenol (TP) by the Folin-Ciocalteu method using gallic acid (SAE10 to $350 \mathrm{mg} \mathrm{mL}^{-1}$ ) as standard, a $\left(y=0.781 x-0.0031 ; R^{2}=0.9959\right)$ calibration curve was used (Sousa et al., 2007). Flavonoids quantification was performed based on aluminum chloride methodology with a standard quercetin $\left(y=0.132 \mathrm{x}+0.0353 \mathrm{R}^{2}=0.9949\right)$ (Peixoto Sobrinho et al., 2008).

The experimental design of the two quantification has three replicates for each concentration and calculation of averages was accompanied by the standard deviation.

\subsection{Antioxidant activity}

DPPH (2,2-diphenyl-1-picrylhydrazyl) analysis was used to determine free radical scavenging activity, where $2 \mathrm{~mL}$ of a DPPH methanol solution $\left(24 \mathrm{mg} 100 \mathrm{~mL}^{-1} \mathrm{de}\right.$ metanol) was added to concentrations of 250, 200, 150, 100,50 and $25 \mathrm{mg} \mathrm{mL}^{-1}$ of ethanol extract. After 30 minutes resting, the samples absorbance were determined by a spectrophotometer UV-VIS, at $515 \mathrm{~nm}$. As negative control was used a DPPH in methanol and rutin $\left(\right.$ Merck $\left.^{\circledR}\right)$ at the same concentrations used on samples as a positive control. The DPPH antioxidant activity percentage remaining on reaction medium $(\% \mathrm{AA})$ was calculated using the Equation 1:

$\% A A=\frac{(A 0-A)}{A 0} \times 100$

where $\mathrm{A}_{0}$ is the DPPH absorbance (negative control) and $\mathrm{A}$ is the samples absorbance with DPPH (Sousa et al., 2007). The effective concentration $\left(\mathrm{EC}_{50}\right)$ was obtained by linear regression.

\subsection{Antifungal activity}

A stock solution was prepared containing $0.2 \mathrm{~g}$ of ethanol extract from the B. crassifolia barks in $100 \mathrm{~mL}$ of ethanol $(99.5 \%)$. From this solution quotes with $0.4,0.6,0.8,1.0$ and $1.2 \mathrm{~mL}$ were separated into PDA (Potato-Dextrose-Agar) cultural medium fondant, until reach a volume of $100 \mathrm{~mL}$, where concentrations of 800 ,
1200, 1600, 2000 and $2400 \mu \mathrm{g} 100 \mathrm{~mL}^{-1}$ were obtained. Two solutions were prepared as control, one containing ethanol content $(99.5 \%)$ added to PDA medium $(2400 \mu \mathrm{g}$ $\left.100 \mathrm{~mL}^{-1}\right)$, named ethanol solution and another one only with PDA medium (without B. crassifolia extract), called control.

Four repetition of each concentration were poured into Petri dishes of $90 \mathrm{~mm}$ in a volume corresponding to $10 \mathrm{~mL}$ per plate. After solidification it was peaked in the center of each plate, a mycelium disc with $5 \mathrm{~mm}$ diameter previously transplanted one week before the procedure. Later, the plates were covered and sealed with plastic film and kept in growth chamber at $25^{\circ} \mathrm{C}$, with a 12 hours photoperiod.

The mycelial growth evaluation was realized through daily measurements of the colonies diameter, obtained by the average of two diametrically opposed measurements, realized until the control group reached the edge of the Petri plate.

Based on the obtained data, the growth inhibition percentage (GIP) was calculated using the Equation 2:

$$
G I P=\frac{\text { control diameter }- \text { treatament diameter }}{\text { control diameter }} \times 100
$$

Data were submitted through variance and regression analysis using the software SISVAR (Ferreira, 2011).

\section{Results and Discussion}

Phytochemical analysis of the ethanol extracts from B. crassifolia indicated the presence of phenolic compounds $(+++)$, tannins $(+++)$, flavonoids $(+++)$, anthraquinones $(++)$, triterpenes $(+++)$, cardiotonic glycosides $(+++)$ and reducing sugars $(++)$ (Figure 1$)$.

The results were confirmed by means of spectrophotometers analysis at the UV-visible region, were the maximum absorption band is $230 \mathrm{~nm}$ ( $\lambda$ máx.MeOH) corresponds to triterpenes, the bands in 280 and $330 \mathrm{~nm}(\lambda$ máx.MeOH) are for phenolic compounds and flavonoids, the band in $280 \mathrm{~nm}$ corresponds to the A ring absorption (hemiacetal) and the

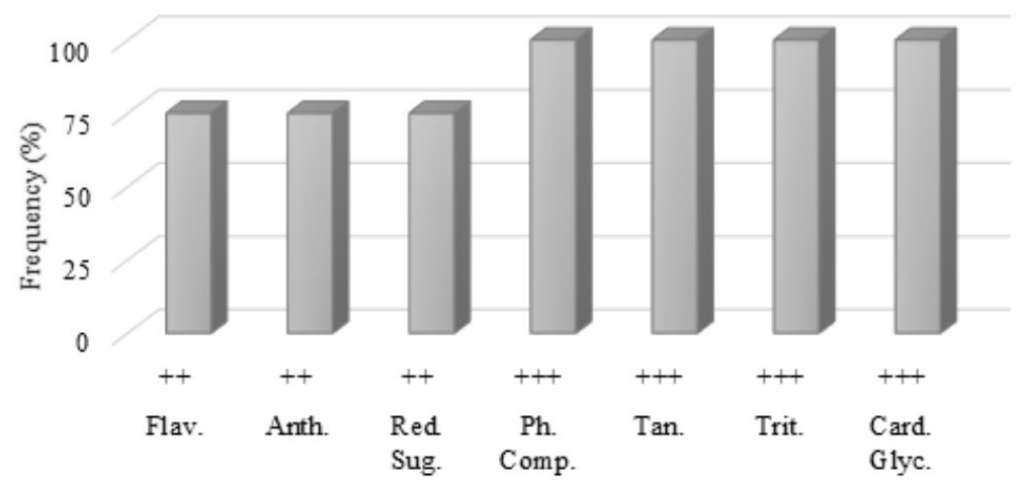

Figure 1. Frequency of secondary metabolites found in the bark extract of B. crassifolia. Flav.: Flavonoids; Anth.: Anthraquinones; Red. Sug.: Reducing sugars; Ph. Comp.: Phenolic compounds; Tan.: Tannins; Trit.: Triterpenes; Card. Glyc.: Cardiotonic Glycosides; $(++)$ moderate intensity; $(+++)$ high intensity. 
band in $370 \mathrm{~nm}$ represents the flavonoids B ring (Figure 2). The presence of anthraquinones was also confirmed due the absorption band in $480 \mathrm{~nm}$ ( $\lambda$ máx. $\mathrm{MeOH})$; bands between 481 and $508 \mathrm{~nm}$ are characteristical of condensed aromatic compounds, which have elevated conjugation level with the carboxil group and carboxilic anthraquinones (Figure 2) (Silverstein et al., 2014).

The flavonoids and triterpenes positives results agreed with the data found by Guilhon-Simplicio and Pereira (2011), which pointed the presence of flavonoids and terpenes, especially triterpenes for species of the Byrsonima genre. In relation to barks of $B$. crassifolia the presence of phenolic compounds, flavonoids and catechins was already described by Geiss et al. (1995).

Total phenols and flavonoids quantification in barks presented values of $202.5 \pm 0.34\left(\mathrm{mg} \mathrm{g}^{-1}\right.$ galic acid) and $178.9 \pm 0.85$ (mg g-1quercetin), respectively. This demonstrates that among the total phenols presented in barks, great part of these belong to the flavonoid group. Studying barks of B. crassifolia, Silva and Rogez (2013), found similar value to the one observed in this paper $(208.1 \pm 9.7 \mathrm{mg}$ g-1) and superior to the one found by Pompeu et al. (2012) that was $58.1 \mathrm{mg} \mathrm{g}^{-1}$ of total phenols for the hydroethanol crude extract of dried leaves of $B$. crassifolia collected at the region of Belem, PA, Brazil. For the crude extract of aerial parts of $B$. gardneriana, the values were superiors

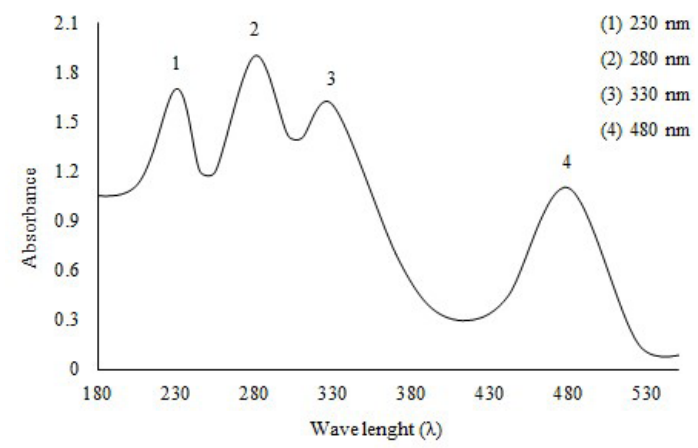

Figure 2. Absorption spectrum of the ethanol extract of the bark of Byrsonima crassifolia $\left(400 \mu \mathrm{m} \mathrm{mL}^{-1}\right)$.
(425.105 \pm 8.523 mg EAG g-1) (Rolim et al., 2013), which suggests that Byrsonima species have high levels of total phenols in their composition. Still, differences found in several studies with $B$. crassifolia, may be associated to the solvent and the extraction method used (Simões et al., 2010), just like geographic localization and environmental factors form the region where plants are collected may influence the presence and intensity of secondary metabolites (Gobbo-Neto and Lopes, 2007).

Regarding the antioxidant activity, the efficient concentration of ethanol extract of $B$. crassifolia used to decrease the initial concentration of DPPH in $50 \%$ was $2.88 \pm 0.15 \mathrm{mg} \mathrm{mL}^{-1}$ and the rutine (positive control) presented CE50 of $2.75 \pm 0.08 \mathrm{mg} \mathrm{mL}^{-1}$. These results point that the extract have antioxidant activity, justified by the presence of phenolic compounds and flavonoids, known by their capacity to redeem free radicals and inhibit possible oxidant damages. The same antioxidant activity of hidro ethanolic extract of Bysonima crassifolia leaves was previously described by (Pompeu et al., 2012) and for others species of the same genre by (Rolim et al., 2013).

In relation to the antifungal activity, there was observed interaction among the different concentrations of ethanol extract of B. crassifolia and plant pathogens (F. solani and $S$. sclerotiorum), all concentrations proportioned different fungi micelial growth inhibition levels, with the GIP varying among 5 and 38\% (Figure 3).

Extract concentrations of 800 and $1600 \mu \mathrm{g} 100 \mathrm{~mL}^{-1}$ reduced over $38 \%$ of $F$. solani growth when compared to the control group, this affirmation is corroborated by regression analysis (Figure 4). Using a 20\% concentration of Indian clove (Syzygium aromaticum L.), Venturoso et al. (2011) observed a high inhibition of $F$. solani, indicating that this pathogen may be controlled by plant extracts.

Others vegetal extracts also indicated inhibitory activity over others Fusarium genre fungi, like $F$. oxysporum, which had its mycelial growth reduced when using ethanol extract of fedegoso (Senna alata L.) (Medeiros et al., 2012 ) and $F$. proliferatum over garlic ethanol extract (Allium sativum L.) (Souza et al., 2007).

Treatments with 2000 and $2400 \mu \mathrm{g} 100 \mathrm{~mL}^{1}$ promoted significant reduction over $S$. sclerotiorum growth, with

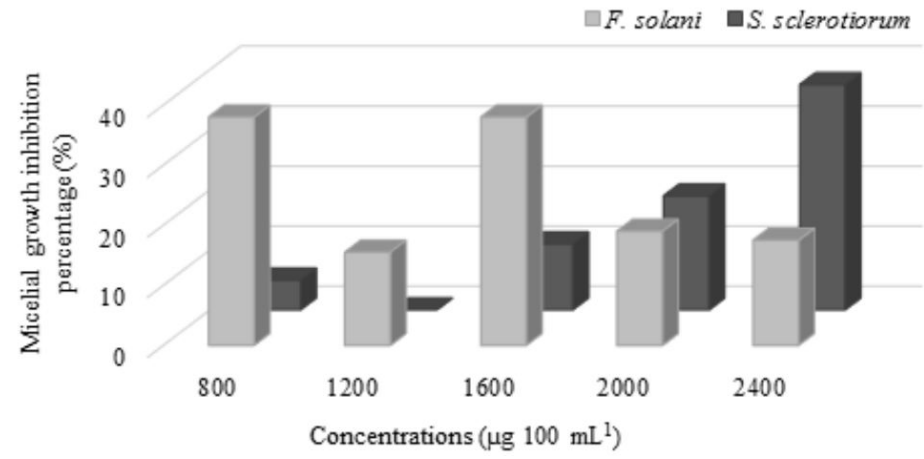

Figure 3. Micelial growth inihbition (\%) of Fusarium solani and Sclerotinia scleotiorum with different concentrations of ethanolic extract of Byrsonima crassifolia. 
a inhibitory effect of 19 and $37.5 \%$, respectively, over control group (Figure 5).

Those in vivo tests as well as their phitochemical analysis allows to evaluate some mechanism evolved in the control of micro-organisms that are plant pathogenic, whose in many times can remain alive in in vivo conditions as related by Rodrigues et al. (2007), using ginger (Zingiber officinalis Roscoe) crude extract applied to lettuce leaves, reducing mycelial growth of S. sclerotiorum in $93 \%$,

There are few studies using $B$. crassifolia extracts in plant pathogens, however Guilhon-Simplicio and Pereira (2011) pointed antifungal properties of the bark, leaves, flowers, fruits and roots of this specie in several pathogens that affect human health.

Naruzawa and Papa (2011) observed that the hydro ethanol extract from barks of $B$. verbascifolia Rich ex. Juss had antifungal activity, affecting mycelial growth and spore germination of Corynespora cassiicola (Berk. and Curt.) Wei and Colletotrichum gloeosporioides (Penz.) Sacc., in barbados cherry plants, which highlights the secondary metabolite antimicrobial activity of Byrsonima genre plants.

Several secondary metabolites from $B$. crassifolia ethanol extract plays significant role in mechanisms that

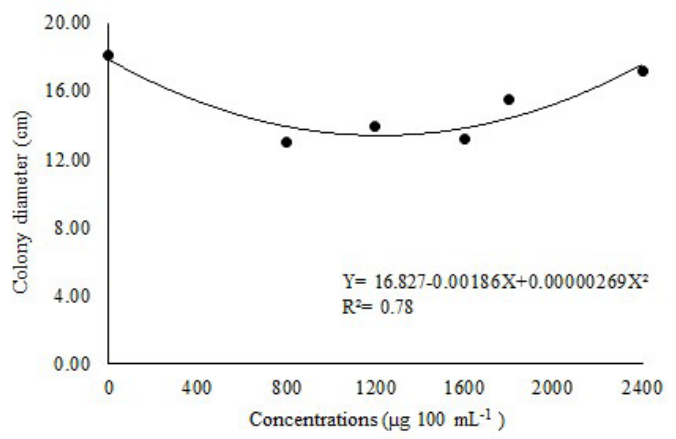

Figure 4. Mycelial growth inihbition of Fusarium solani using different concentrations of Byrsonima crassifolia ethanol extract.

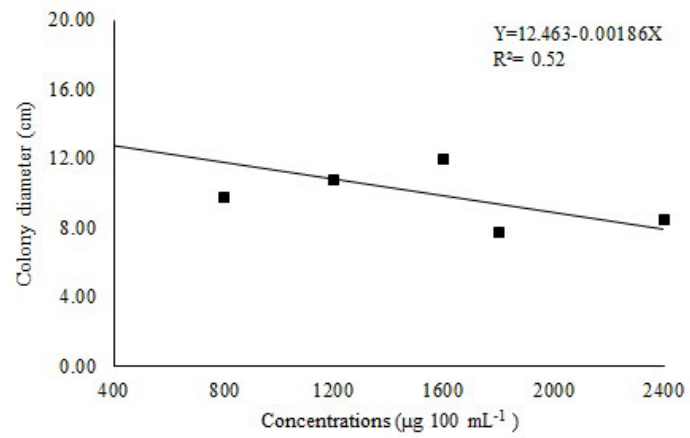

Figure 5. Mycelial growth inhibition of Sclerotinia sclerotiorum using different concentrations of Byrsonima crassifolia ethanol extract. activate plants defence, such as triterpenes, flavonoids, phenolic compounds and tannins.

According to Agrios (2005) phenolic compounds and tannins are pointed as responsible by young plant tissues resistance to plant pathogens, being powerful inhibitors of several hydrolytical enzymes produced by those pathogens during their penetration in plants cells and tissues.

On the same way, flavonoids also actuate as elicitors and/or defense chemical mechanisms against virus, bacteria and fungi, (Zuanazzi and Montanha, 2004). Their fungi toxicity depends on the amount of methylated groups and the number of substituents on the aromatics ring formation, which makes them more toxic, interfering on fungi membranes (Harborne, 1994). By the other side, it's observed that extracts from barks of $B$. crassifolia have predominance of polyphenols and derivates (flavonoids, tannins and anthraquinones). These groups have in their structure the carboxyl group $(\mathrm{OH})$, which has the ability to link with microorganisms enzyme receptors, inhibiting protein synthesis. These informations are not well established; however, Cushnie and Lamb (2005) pointed that flavonoids favor pathogens metabolic modifications, acting inhibiting nucleic acid synthesis during cytoplasmatic membrane formation and energetic metabolism.

Anthraquinones present condensed aromatic groups (lipophilic), carboxyl groups and carboxylics, which can act breaking the membrane and inhibit metabolism. Many activities are attributed to anthraquinones found in nature specially their oxidant potential which triggers cellular apoptosis; this effect occurs by intercalation among vicinal nucleotides from DNA, by ionic and Van der Waals interactions with anthraquinones, blocking polymerases and interfering on protein synthesis (Silva et al., 2003; Jampilek, 2016).

Triterpenes have a basic lipofilic squeleton, which makes easier to break the cells walls, facilitating the flow of constituents as well as cardiotonic glycosides to the extract, both of them act the same way because these cardiotonic glycosides have a triterpenic nature, making easier to break the cellular membrane and with their polar part inside the cell, they act disabling fungi aminoacids residual receptors.

The biological activity of these constituents corroborates Schwan-Estrada et al. (2000) studies, which pointed that plant extract potentials to control plant pathogens in essays is related not only due their toxic action over mycelium and spore germination in fungi but also by inducting substances involved on plant defence mechanisms.

This study observed a $4 \%$ sugars presence on $B$. crassifolia, extracts, obtained by ${ }^{\circ}$ Brix, to classify sugar kinds the extract was submitted to a lugol reaction, presenting negative result, indicating the presence of mono and disaccharides, from Barfoed and Seliwanoff reactions was possible to determine that the extract had mainly monosaccharides and ketohexoses. Monosacharides are a carbon source to fungi, a major component to their growth and sporulation, once their related to their nutrition process (Sangeetha and Rawal, 2008). This way, despite 
the presence of free sugar in extract, which benefits fungal growth mechanisms, it was observed the inhibition of the plant pathogens $F$. solani e $S$. sclerotiorum. It is imperative to highlight the importance of sugar evaluations in plant extracts to ensure their antifungal action.

A point to be taken in account is the $B$. crassifolia extract $\mathrm{pH}$, which in this study was $4.24 \pm 0.09$, indicating an acidity factor. However, knowing that soils with acid $\mathrm{pH}$ favor plant pathogens development, this achieved to reduce mycelial growth of the fungi studied, which proves their antifungal activity, factor related to secondary metabolites presented on $B$. crassifolia barks ant their potential to be used as a pathogen control of plants in familiar and organic agriculture

Considering that the fungi tested are difficult to control because they form colonies that remaining viable on soil for a long period, the result obtained in this study is considered satisfactory. Being able to suggest that the extract presents potential to be used as an alternative way to control fungi plant pathogens, leading to reduce negative impacts on environment and human health caused by using of agro-toxics.

\section{Conclusion}

B. crassifolia extracts proportioned the inhibition of mycelial growth on fungi studied. The antifungal potential is probably related to the plant chemical constitution, which have a massive amount of secondary metabolites, such as flavonoids, phenolic compounds, tannins and anthraquinones, and triterpenes, which has an antioxidant activity, that are related to plant defense systems against other organisms.

\section{Acknowledgements}

We thank CAPES, for the masters scholarship granted, we also thank CNPq for the productivity research scholarship granted (PQ2). To CNPq and FUNDECT for financial support.

\section{References}

AGRIOS, G.N.,2005. How plants defend themselves against pathogens. In: G.N. AGRIOS, ed. Plant pathology. 5th ed. California: Academic Press, pp. 93-114.

BUENO, C.J., AMBRÓSIO, M.M.Q. and SOUZA, N.L., 2007. Produção e avaliação da sobrevivência de estruturas de resistência de fungos fitopatogênicos habitantes do solo. Summa Phytopathologica, vol. 33, no. 1, pp. 47-55. http://dx.doi. org/10.1590/S0100-54052007000100007.

CELOTO, M.I.B., PAPA, M.F.S., SACRAMENTO, L.V.S. and CELOTO, F.J., 2008. Atividade antifúngica de extratos de plantas a Colletotrichum gloeosporioides. Acta Scientiarum. Agronomy, vol. 30, no. 1, pp. 1-5. http://dx.doi.org/10.4025/actasciagron. v30i1.1104.

CUSHNIE, T.P. and LAMB, A.J., 2005. Antimicrobial activity of flavonoids. International Journal of Antimicrobial Agents, vol. 26, no. 5, pp. 343-356. PMid:16323269. http://dx.doi.org/10.1016/j. ijantimicag.2005.09.002.

FERREIRA, D.F., 2011. Sisvar: a computer statistical analysis system. Ciência e Agrotecnologia, vol. 35, no. 6, pp. 1039-1042. http://dx.doi.org/10.1590/S1413-70542011000600001.

FONTOURA, F.M., MATIAS, R., LUDWIG, J., OLIVEIRA, A.K.M., BONO, J.A.M., MARTINS, P.F.R., CORSINO, J. and GUEDES, N.M.R., 2015. Seasonal effects and antifungal activity from bark chemical constituents of Sterculia apetala (Malvaceae) at Pantanal of Miranda, Mato Grosso do Sul, Brazil. Acta Amazonica, vol. 45, no. 3, pp. 283-292. http://dx.doi. org/10.1590/1809-4392201500011.

GEISS, F., HEINRICH, M., HUNKLER, D. and RIMPLER, H., 1995. Proanthocyanidins with $(+)$-epicatechin units from Byrsonima crassifolia bark). Phytochemistry, vol. 39, no. 3, pp. 635-643. http://dx.doi.org/10.1016/0031-9422(94)00934-L.

GOBBO-NETO, L. and LOPES, N.P., 2007. Plantas medicinais: fatores de influência no conteúdo de metabólitos secundários. Química Nova, vol. 30, no. 2, pp. 374-381. http://dx.doi.org/10.1590/ S0100-40422007000200026.

GUILHON-SIMPLICIO, F. and PEREIRA, M.M., 2011. Aspectos químicos e farmacológicos de Byrsonima (Malpiguiaceae). Quimica Nova, vol. 34, no. 6, pp. 1032-1041. http://dx.doi.org/10.1590/ S0100-40422011000600021.

HARBORNE, J.B., 1994. Introduction to ecological biochemistry. 4th ed. New York: Academic Press. 384 p.

INSTITUTO BRASILEIRO DE GEOGRAFIA E ESTATÍSTICAIBGE, 2009 [viewed 22 March 2016]. Censo Agropecuário 2006: agricultura familiar, primeiros resultados [online]. Rio de Janeiro: IBGE. Available from: http://www.fao.org/fileadmin/templates/ess/ ess_test_folder/World_Census_Agriculture/Country_info_2010/ Reports/BRA_BRA_REP_2006.pdf

JAMPILEK, J., 2016. Potential of agricultural fungicides for antifungal drug discovery. Expert Opinion on Drug Discovery, vol. 11, no. 1, pp. 1-9. PMid:26549424. http://dx.doi.org/10.151 7/17460441.2016.1110142.

MARTÍNEZ-VÁZQUEZ, M., GONZÁLEZ-ESQUINCA, A.R., CAZÁRES, L.M.L., GUTIÉRREZ, M.N.M. and GARCÍAARGÁEZ, A.N., 1999. Antimicrobial activity of Byrsonima crassifolia (L.) H.B.K. Journal of Ethnopharmacology, vol. 66, no. 1, pp. 79-82. PMid:10432211. http://dx.doi.org/10.1016/ S0378-8741(98)00155-X.

MATOS, F.J.A.,2009. Introdução a fitoquímica experimental. 2nd ed. Fortaleza: Universidade Federal do Ceará. 141 p.

MEDEIROS, E.V., VIANA, M.G., ALBUQUERQUE, C.C., VIANA, F.A. and SILVA, K.M.B., 2012. Extrato etanólico de Senna alata no controle de Fusarium oxysporum, causador da murcha-de-fusarium do meloeiro. Revista Brasileira de Engenharia Agricola e Ambiental, vol. 16, no. 11, pp. 1166-1170. http://dx.doi. org/10.1590/S1415-43662012001100004.

NARUZAWA, E.S. and PAPA, M.F.S., 2011. Antifungal activity of extracts from brazilian Cerrado plants on Colletotrichum gloeosporioides and Corynespora cassiicola. Revista Brasileira de Plantas Medicinais, vol. 13, no. 4, pp. 408-412. http://dx.doi. org/10.1590/S1516-05722011000400006.

OLIVEIRA, A.K.M., OLIVEIRA, N.A., RESENDE, U.M. and MARTINS, P.F.R.B., 2011. Ethnobotany and traditional medicine of the inhabitants of the Pantanal Negro sub-region and the raizeiros of Miranda and Aquidauana, Mato Grosso do 
Sul, Brazil. Brazilian Journal of Biology $=$ Revista Brasileira de Biologia, vol. 71, no. 1, suppl. 1, pp. 283-289. PMid:21537601. http://dx.doi.org/10.1590/S1519-69842011000200007.

PADUA, J.B., SCHLINDWEIN, M.M. and GOMES, E.P., 2013. Agricultura familiar e produção orgânica: uma análise comparativa considerando os dados dos censos de 1996 e 2006. Interações, vol. 14 , no. 2 , pp. $225-235$. http://dx.doi.org/10.1590/S151870122013000200009

PEIXOTO SOBRINHO, T.J.S., SILVA, C.H.T.P., NASCIMENTO, J.E., MONTEIRO, J.M., ALBUQUERQUE, U.P. and AMORIM, E.L.C., 2008. Validação de metodologia espectrofotométrica para quantificação dos flavonoides de Bauhinia cheilantha (Bongard) Steudel. Revista Brasileira de Ciências Farmacêuticas, vol. 44, no. 4, pp. 683-689. http://dx.doi.org/10.1590/S151693322008000400015

PEREIRA, J.O.P.P. and FREITAS, B.M., 2002. Estudo da biologia floral e requerimentos de polinização do muricizeiro (Byrsonima crassifolia L.). Revista Ciência Agronômica, vol. 33, no. 2, pp. 5-12.

POMPEU, D.R., ROGEZ, H., MONTEIRO, K.M., TINTI, S.V. and CARVALHO, J.E., 2012. Capacidade antioxidante e triagem farmacológica de extratos brutos de folhas de Byrsonima crassifolia e de Inga edulis. Acta Amazonica, vol. 42, no. 1, pp. 165-172. http://dx.doi.org/10.1590/S0044-59672012000100019.

POTT, A. and POTT, V.J., 1994. Plantas do Pantanal. Corumbá: Embrapa Pantanal. 320 p.

POTT, A., OLIVEIRA, A.K.M., DAMASCENO-JUNIOR, G.A. and SILVA, J.S.V., 2011. Plant diversity of the Pantanal wetland. Brazilian Journal of Biology $=$ Revista Brasileira de Biologia, vol. 71, no. 1, suppl. 1, pp. 265-273. PMid:21537599. http:// dx.doi.org/10.1590/S1519-69842011000200005.

REMIÃO, J.O.R., SIQUEIRA, A.J.S. and AZEVEDO, A.M.P., 2003. Bioquímica: guia de aulas práticas. Porto Alegre: EDIPUCRS. 214 p.

RODRIGUES, E., SCHWAN-ESTRADA, K.R.F., FIORI-TUTIDA, A.C.G., STANGARLIN, J.R. and CRUZ, M.E.S.C., 2007. Fungitoxicidade, atividade elicitora de fitoalexinas e proteção de alface em sistema de cultivo orgânico contra Sclerotinia sclerotiorum pelo extrato de gengibre. Summa Phytopathologica, vol. 33 , no. 2 , pp. 124-128. http://dx.doi.org/10.1590/S010054052007000200004

ROLIM, T.L., WANDERLEY, F.T.S., CUNHA, E.V.L., TAVARES, J.F., OLIVEIRA, A.M.F. and ASSIS, T.S., 2013. Constituintes químicos e atividade antioxidante de Byrsonima gardneriana (Malpiguiaceae). Química Nova, vol. 36, no. 4, pp. 524-527. http://dx.doi.org/10.1590/S0100-40422013000400007.

SANGALLI, A.R. and SCHLINDWEIN, M.M., 2013. A contribuição da agricultura familiar para o desenvolvimento rural de Mato Grosso do Sul - Brasil. REDES: Revista do Desenvolvimento Regional, vol. 18, no. 3, pp. 82-99. http://dx.doi.org/10.17058/ redes.v18i3.2592

SANGEETHA, C.G. and RAWAL, R.D., 2008. Nutritional Studies of Colletotrichum gloeosporioides (Penz.) Penz. and Sacc. the incitant of mango anthracnose. World Journal of Agricultural Sciences, vol. 4, no. 6, pp. 717-720.
SCHWAN-ESTRADA, K.R.F., STANGARLIN, J.R. and CRUZ, M.E.S., 2000. Uso de extratos vegetais no controle de fungos fitopatogênicos. Revista Floresta, vol. 30, no. 1-2, pp. 129-137.

SILVA, A. C., SALES, N.L.P., ARAÚJO, A.V. and CALDEIRAJÚNIOR, C.F., 2009. Efeito in vitro de compostos de plantas sobre o fungo Colletotrichum gloeosporioides Penz. isolado do maracujazeiro. Ciência e Agrotecnologia, vol. 33, no. special, pp. 1853-1860. http://dx.doi.org/10.1590/S1413-70542009000700026.

SILVA, J.J.M. and ROGEZ, H., 2013. Avaliação da estabilidade oxidativa do óleo bruto de açaí (Euterpe oleraceae) na presença de compostos fenólicos puros de extratos vegetais amazônicos. Química Nova, vol. 36, no. 3, pp. 400-406. http://dx.doi.org/10.1590/ S0100-40422013000300009.

SILVA, M.N., FERREIRA, V.F. and SOUZA, M.C.B.V., 2003. Um panorama atual da química e da farmacologia de naftoquinonas, com ênfase na beta-lapachona e derivados. Química Nova, vol. 26, no. 3, pp. 407-416. http://dx.doi.org/10.1590/S010040422003000300019 .

SILVERSTEIN, R.M., WEBSTER, F.X., KIEMLE, D.J. and BRYCE, D.L., 2014. Spectrometric identification of organics compounds. 8th ed. Nova Jersey: John Wiley \& Sons. 464 p.

SIMÕES, C.M.O., SCHENKEL, E.P., GOSMANN, G., MELLO, J.C.P., MENTZ, L.A. and PETROVICK, P.R., 2010. Farmacognosia: da planta ao medicamento. 6th ed. Porto Alegre/Florianópolis: Editora da UFRGS/Editora da UFSC. 1104 p.

SOUSA, C.M.M., SILVA, H.R., VIEIRA-JÚNIOR, G.M., AYRES, M.C.C., CHARLLYTON, L.S.C., DELTON, S.A., CAVALCANTE, L.C.D., BARROS, E.D.S., ARAUJO, P.B.M., BRANDRÃO, M.S. and CHAVES, M.H., 2007. Fenóis totais e atividade antioxidante de cinco plantas medicinais. Química Nova, vol. 30, no. 2, pp. 351-355. http://dx.doi.org/10.1590/S0100-40422007000200021.

SOUZA, A.E.F., ARAÚJO, E. and NASCIMENTO, L.C., 2007. Atividade antifúngica de extratos de alho e capim-santo sobre o desenvolvimento de Fusarium proliferatum isolado de grãos de milho. Fitopatologia Brasileira, vol. 32, no. 6, pp. 465-471. http://dx.doi.org/10.1590/S0100-41582007000600003.

VENTUROSO, L.R., BACCHI, L.M.A., GAVASSONI, W.L., CONUS, L.A., PONTIM, B.C.A. and BERGAMIN, A.C., 2011. Atividade antifúngica de extratos vegetais sobre o desenvolvimento de fitopatógenos. Summa Phytopathologica, vol. 37, no. 1, pp. 18-23. http://dx.doi.org/10.1590/S0100-54052011000100003.

ZACARONI, L.M., CARDOSO, M.G., SOUZA, P.E., PIMENTEL, F.A., GUIMARÃES, L.G.L. and SALGADO, A.P.S.P., 2009. Potencial fungitóxico do óleo essencial de Piper hispidinervum (pimenta longa) sobre os fungos fitopatogênicos Bipolaris sorokiniana, Fusarium oxysporum e Colletotrichum gloeosporioides. Acta Amazonica, vol. 39, no. 1, pp. 193-198. http://dx.doi.org/10.1590/ S0044-59672009000100020

ZUANAZZI, J.A.S. and MONTANHA, J.A., 2004. Flavonoides. In: C.M.O SIMÕES, E.P SCHENKEL, G GOSMANN, J.C.P. MELLO, L.A. MENTZ and P.R. PETROVICK, eds. Farmacognosia: da planta ao medicamento. 5th ed. Porto Alegre/Florianópolis: Editora da UFRGS, Editora da UFSC, pp. 577-614. 